\title{
KONFLIK ISTRI DAN MERTUA PADA KELUARGA TENAGA KERJA INDONESIA DI DESA BOJONGKUNCI
}

\author{
Erfina Agesty A, Elly Malihah \\ Universitas Pendidikan Indonesia \\ Jl. Dr.Setiabudi 229 Bandung 40154, Jawa Barat, Indonesia \\ Email: Erfina.agesty.a@student.upi.edu
}

\begin{abstract}
Abstrak Penelitian ini dilatarbelakangi karena adanya konflik internal keluarga Tenaga Kerja Indonesia di wilayah Desa Bojongkunci, khususnya konflik yang terjadi antara menantu dan mertua keluarga TKI. Penelitian ini bertujuan untuk mengetahui faktor yang melatarbelakangi konflik internal yang terjadi pada keluarga TKI di wilayah desa Bojongkunci. Penelitian ini menggunakan pendekatan kualititatif dan metode deskriptif untuk mempaparkan hasil penelitianya. Pengumpulan data pada penelitian ini menggunakan teknik observasi, teknik wawancara, dan studi dokumentasi dari pihak-pihak yang terpercaya. Informan penelitian terdiri dari istri dari keluarga TKI, tokoh masyarakat, dan warga yang menjadi tetangga dari keluarga TKI. Hasil penelitian ini menunjukkan bahwa adanya perubahan sikap dari anak, istri dan mertua pada saat menjadi keluarga seorang TKI menjadi faktor yang melatarbelakangi konflik internal yang terjadi pada keluarga TKI di wilayah Desa Bojongkunci.

Kata kunci: $\quad$ konflik, keluarga, tenaga kerja indonesia, menantu dan mertua
\end{abstract}

\section{PENDAHULUAN}

Keluarga merupakan tempat tumbuh kembang pertama dari seorang individu, dari keluarga yang harmonis seseorang akan mendapatkan pembelajaran yang tak ternilai, mulai dari kasih sayang orang tua terhadap anak hingga anak yang menjadi suatu kebanggaan bagi keluarga. Keutuhan keluarga terjadi karena adanya saling menghormati antara anggota satu dengan anggota yang lainnya, adanya kasih sayang antara satu dengan yang lainnya. Keluarga yang utuh adalah keluarga yang anggotanya masih tinggal dalam satu atap dan menjalani aktivitas sesuai dengan peranya masingmasing, namun tetap memiliki waktu luang untuk berkumpul bersama dengan keluarga.

Menurut Surya (dalam Santi. 2015, hlm 468) "antara kebahagiaan dan keharmonisan terjadi keterkaitan yang erat dan saling menentukan. Keluarga yang bahagia adalah keluarga harmonis dan sebaliknya keluarga harmonis adalah keluarga bahagia." Keharmonisan merupakan kondisi hubungan antar pribadi yang melandasi keluarga bahagia. Hubungan antar pribadi merupakan awal dari sebuah keharmonisan. Hal ini mengandung arti bahwa keharmonisan sulit untuk terwujud tanpa adanya hubungan antar pribadi, baik dalam keluarga maupun antar keluarga.
Salah satu faktor yang menjadi alasan terpisahnya sebuah keluarga adalah dalam mencari pekerjaan, pilihan menjadi seorang tenaga kerja Indonesia lah yang menjadi pilihan banyak keluarga untuk dijadikan profesi, karena tidak butuh pendidikan yang tinggi untuk menjadi seorang tenaga kerja Indonesia. Ketika menjadi tenaga kerja Indonesia telah dipilih oleh para kepala keluarga, pada hal ini istri yang banyak bertanggung jawab atas kehidupan anak-anaknya selama ayahnya pergi sebagai tenaga kerja Indonesia, Istri bekerja duakali lipat dibanding biasanya, yaitu dalam hal mendidik anak dan hal-hal lain yang biasanya dilakukan oleh suami apabila suami berada dalam satu atap.

Selain menjalin keharmonisan bersama keluarga inti, keharmonisan pun harus dijalin dengan keluarga besar atau orangtua dari masing-masing pihak atau biasa yang disebut dengan mertua, mertua akan membekali pengalaman ataupun ilmu yang lainnya tentang bagaimana membuat mahligai pernikahan yang sakinah mawadah warahmah dan jauh dari konflik, tetapi tidak semua mertua berbagi hal yang positif terhadap keluarga baru anaknya, terkadang timbul rasa takut tersaingi oleh menantunya. Menurut Ihromi (1995, hlm 468) "Hubungan antara menantu dan mertua ternyata banyak yang tidak selalu berjalan mulus." Perbedaan pendapat antara istri dan mertua terkadang cukup terlihat sangat tajam dalam kehidupan berkeluarga, dari perbedaan pendapat itulah timbul konflik yang terjadi pada istri 
dan mertua, jika tidak dapat diselesaikan secara baik-baik hal ini dapat menimbulkan disorganisasi keluarga, dan jauh dari itu konflik ini diam-diam dilakukan dibelakang suami ataupun anak dari mertua tersebut, sehingga suami yang seorang Tenaga Kerja Indonesia itu tidak mengetahui apa yang sebenarnya terjadi pada hubungan istri dan orangtuanya.

Adapun yang perlu diketahui dalam melakukan komunikasi baik dari pihak menantu maupun mertua yaitu dalam berkomunikasi harus memiliki sikap etika dan menghindari mengucapkan kata-kata yang kurang sopan. Untuk meningkatkan komunikasi baik dari pihak menantu maupun mertua maka berikut solusi dalam meningkatkan efektifitas komunikasi yang baik menurut Wiryanto (dalam Santi. 2015, hlm 469) "yaitu keterbukaan (opennes), empati (empathy), dukungan (supportiveness), rasa positif (positivenes) dan kesetaraan (eqauality). Dalam hal tersebut informasi yang diterima dalam menghadapi hubungan antara menantu maupun mertua harus memiliki perasaan positif untuk menciptakan situasi komunikasi kondusif dan interaksi efektif." Dan pada saat tertentu antara istri dan mertua itu sedang bertemu, mereka akan sama-sama bermain peran untuk menutupi konflik yang terjadi antara mereka kepada anggota keluarga lainnya.

Masalah ini sangat penting untuk diteliti karena dengan ditelitinya masalah ini, keluarga tenaga kerja Indonesia mampu menjaga komunikasi yang baik antar keluarga, tidak hanya pada keluarga inti saja tetapi pada keluarga besar juga, dan dapat lebih meningkatkan keharmonisan keluarga. Oleh sebab itu peneliti tertarik untuk mengangkat permasalahan ini.

\section{METODE PENELITIAN}

Penelitian ini merupakan penelitian kualitatif dengan menggunakan metode deskripsi. Penelitian ini dilakukan di wilayah Desa BojongKunci Kecamatan Pameungpeuk. Informan dalam penelitian ini sebanyak 6 orang yang terdiri dari tiga orang informan utama yaitu istri keluarga TKI dan tiga orang informan pangkal.yaitu warga, tokoh masyarakat dan ibu kader Desa Bojongkunci. pihakpihak tersebut dianggap memiliki informasi yang diperlukan oleh peneliti untuk mengungkapkan dan menganalisis konflik yang telah terjadi. Pemilihan partisipan ini menggunakan purposive sampling, dan hasil penelitian diperoleh dengan teknik observasi, studi dokumentasi dan wawancara.

\section{HASIL DAN PEMBAHASAN}

Berdasarkan hasil penelitian konflik yang terjadi pada konflik internal keluarga TKI sangat beragam, faktor yang melatarbelakangi konflik internal yang terjadi pada keluarga TKI di wilayah desa Bojongkunci yaitu Pertama, adanya sifat Konsumtif yang dilakukan oleh seorang istri Adanya sifat Konsumtif yang dilakukan oleh seorang istri. faktor penyebab yang mempengaruhi munculnya perilaku konsumtif menurut Suyasa dan Fransisca (dalam Wardhani, 2009, hlm. 28-29) yaitu :

1. Hadirnya Iklan. Iklan merupakan salah satu cara seorang produsen untuk menjual barangnya dengan cara yang menarik yang ditujukan kepada masyarakat luas lewat suatu media bertujuan agar mempengaruhi masyarakat agar membeli produk yang ditawarkan.

2. Konformitas. Konformitas pada sikap konsumtif ini biasanya terajdi pada remaja perempuan, hal ini disebabkan karena keinginan yang kuat pada remaja untuk tampil lebih menarik dan dapat diterima pada kelompoknya.

3. Gaya Hidup. Munculnya arus globalisasi dan masuknya budaya barat dapat menjadi salah satu yang menyebabkan perubahan pada gaya hidup seseorang untuk bersifat konsumtif. Dengan pembelian barang yang bermerek dan mewah dapat meningkatkan status sosial seseorang.

4. Kartu Kredit. Kartu kredit menyediakan fasilitas yang sangat menarik bagi penggunanya, sehingga penggunanya dapat menggunakan batas kredit yang ada tanpa takut tidak memilki uang pada saat berbelanja.

Sikap konsumtif ini tidak terlalu diperhatikan oleh menantu bahwa dengan timbulnya sikap ini akan menimbulkan masalah yang lebih besar dengan mertua. Pada awalnya mertua pun tidak ikut campur terhadap sikap konsumtif yang dilakukan oleh mertuanya namun dirasa sikap konsumtifnya sudah terlalu berlebihan sehingga mertua mulai ikut campur terhadap keluarga anaknya.

Kedua, Adanya kekhawatiran tinggi mertua terhadap pengeluaran biaya yang dilakukan oleh menantu. kurangnya keterbukaan masalah keuangan keluarga dapat menimbulkan kesalahpahaman antara menantu dan mertua, sehingga adanya kekhawatiran tinggi dari mertua terhadap pengeluaran biaya yang dilakukan oleh menantu, sikap ini berhubungan dengan adanya sikap konsumtif yang terjadi pada istri seorang TKI yang pada umumnya memiliki perubahan baru bagi para istri seorang TKI untuk mengikuti proses perkembangan yang terjadi di lingkungan sekitarnya. Namun tentunya hal ini tidak terjadi secara menyeluruh kepada istri seorang TKI dan tidak seharusnya pula mertua memukul rata 
persepsi bahwa istri seorang TKI akan selalu bersikap konsumtif dan mengeluarkan biaya berlebihan tanpa diketahui oleh suaminya. Dengan adanya sikap seperti ini yang dilakukan mertua dapat membuat menantu merasa tidak dihargai karena tidak diberi kepercayaan yang baik dari mertuanya dalam mengatur keuangan keluarganya, seharusnya mertua memiliki sikap yang positif terhadap menantunya agar terjalinnya hubungan yang harmonis antara menantu dan mertua keluarga TKI di wilayah Desa Bojongkunci.

Ketiga, Adanya sikap tegas mertua (adanya sindiran dan berbicara pedas terhadap menantu) yang membuat sakit hati menantu. Sindiran yang dilontarkan dari mertua terhadap menantu dikarenakan adanya suatu hal yang tidak sejalan atau tidak sepaham antara mertua dengan menantu di lingkup keluarga TKI yang berada di Desa Bojongkunci, dan menantu mengikuti segala nasihat yang diberikan oleh mertuanya namun akan berbeda halnya dengan sikap mertua yang terus-terusan memberikan sindiran dan kritik pedas terhadap sikap menantunya yang mengatur keluarga intinya selama suami menjadi seorang TKI, hal ini akan menimbulkan perasaan sakit hati dari menantu karena segala yang dilakukannya tidak dianggap benar dalam mengatur keluarrganya selama suaminya menjadi seorang TKI. Marotz and Cowan mengungkapkan (2014) bahwa "Dalam hubungan mertua dan menantu, peran mertua jauh lebih berperan penting dibandingkan dengan menantu dalam kehidupan dua generasi keluarga, dan menjadi masalah yang selalu terjadi dalam keluarga. Mertua dan menantu selalu konsisten terhadap apa yang mereka alami, sehingga konflik akan terus berlangsung sehingga akan menjadikan salah satu dari mereka mengalami depresi atau stress". Dapat disimpulkan bahwa apabila sikap ini berlanjut secara terus menerus terjadi diantara menantu dan mertua keluarga TKI dan mereka tetap saling pada keputusannya masing-masing dalam mengatur keluarga, maka hal ini akan menmbulkan depresi atau stress diantara salah satu dari mereka, karena tidak adanya satu kesatuan yang dialami oleh mereka sehingga akan terus berlanjut ketidaksepahaman antara menantu dan mertua keluarga TKI di wilayah Desa Bojongkunci.

Keempat, Kurangnya komunikasi antara menantu dan mertua sehingga sering terjadinya kesalahpahaman. Terjadinya konflik antara menantu dan mertua sebelum suami menjadi seorang TKI dapat menjadi salah satu alasan ketidakharmonisannya antara mertua dan menantu dalam keluarga setelah suami menjadi seorang TKI, meningkatnya kesalahpahaman antara mentua dan menantu dapat lihat ketika suami menjadi seorang TKI karena tidak adanya penghubung komunikasi diantara mereka dan kurangnya inisiatif dari menantu ataupun mertua untuk memiliki komunikasi yang baik dengan menantu ataupun keluarga dari anaknya, padahal dengan berangkatnya suami menjadi seorang TKI menjadi salah satu kesempatan antara menantu dan mertua untuk berkomunikasi secara langsung dalam kehidupan sehari-hari dan saling bertukar pikiran dalam mengatur dan mengawasi keluarga anaknya seperti yang diungkapkan oleh Zakaria (2012) bahwa hal yang harus diperhatikan metua adalah "Berikan saran dan nasehat yang tulus, terlebih jika mereka memintanya".

Kelima, perkembangan anak yang tidak baik sehingga mertua menyalahkan menantunya. Keluarga memiliki peran yang sangat kuat pengaruhnya terhadap pendewasaan anak, keluarga harus dapat memberikan sosialisasi dan pengawasan yang baik terhadap anaknya, sehingga anak tidak memilih jalan yang salah untuk bergaul dilingkungan sekitarnya, perkembangan anak yang kurang baik dapat disebabkan oleh pola asuh yang salah sehingga anak selalu ingin dipenuhi keinginannya. Apabila masalah ini telah sampai pada telinga mertua ataupun orangtua, mereka akan ikut campur terhadap penanganan konflik yang dibuat oleh anaknya tersebut, namun terkadang hal yang ditakutkan oleh istri seorang TKI dalam dianggap gagalnya mengurus anak oleh mertua menjadi kenyataan. Dari pergaulan anak yang salah sehingga menimbulkan konflik dalam keluarganya dapat membuat seorang mertua memiliki persepsi bahwa menantu tidak memiliki pola asuh yang baik dalam mengurus dan mendidik anak sehingga dipandang sebelah mata oleh mertuanya.

\section{KESIMPULAN}

Konflik Internal antara menantu dan mertua pada keluarga TKI di wilayah Desa Bojongkunci terjadi karena adanya beberapa faktor yang melatarbelakangi yaitu adanya sifat konsumtif yang dilakukan oleh seorang istri hal tersebut terjadi karena adanya perubahan gaya hidup yang disebabkan oleh pendapatan yang keluarganya miliki semakin tinggi, Adanya kekhawatiran tinggi mertua terhadap pengeluaran biaya yang dilakukan oleh menantu, adanya sikap tegas mertua, pada hal ini sikap tegas yang diperlihatkan oleh mertua adalah berbicara pedas dan melakukan sindiran kepada menantunya atas segala perilaku yang dilakukan oleh menantunya yang berperan ganda pada saat suaminya menjadi seorang TKI. Kurangnya komunikasi antara menantu dan mertua sehingga 
terjadinya kesalahpahaman yang disebabkan kurangnya intensitas bertemu dan berkomunikasi dengan alasan tidak ada suami sebagai penghubung. Perkembangan anak yang tidak baik sehingga mertua menyalahkan menantunya, sikap ini terjadi karena mertua memiliki anggapan bahwa menantu tidak baik dan benar dalam mengasuh dan mendidik anak selama suaminya menjadi TKI.

\section{REFERENSI}

Ihromi, T. (1995). Kajian Wanita dalam Pembangunan. Jakarta: Yayasan Obor Indonesia

Marotz-Baden, R. (2014). Mothers-in-Law and Daughters-in-Law: The Effects of Proximity on Conflict and Stress. Family Relation, Vol 38, No.04, hlm 500-501.

Santi, Y. (2015). Peran Komunikasi Interpersonal Dalam Menjaga Hubungan Yang Harmonis Antara Mertua Dan Menantu Perempuan. JISIP: Jurnal Ilmu Sosial dan Ilmu Politik, Vol 4, No.3, hlm 468-469

Wardhani, M.D. (2009). Hubungan Antara Konformitas Dan Harga Diri Dengan Perilaku Konsumtif Pada Remaja Putri. Skripsi. Universitas Sebelas Maret.

Zakaria, Edi. 2012. Peranan Mertua dalam Pernikahan. [Online] Tersedia di: 